\title{
Multiple Taxation as a Bane of Business Development in Nigeria
}

\author{
Oseni Michael \\ Department of Accountancy, The Polytechnic, Ibadan, Nigeria \\ osenimike@gmail.com
}

\section{Doi:10.5901/ajis.2014.v3n1p121}

\begin{abstract}
The study examines the appropriateness of multiple taxes in developing nations like Nigeria. Despite clear and unambiguous legislations that contain list of fees and taxes to be collected, all tiers of governments, ministries, departments and agencies are involved in collecting taxes that are not within this list. Various names are coined for these multiple taxes. The study used content analysis method to highlight challenges that are peculiar to Nigeria. Introducing taxes that are not backed by laws to investors because of the apparent profitability of their businesses and the attempt to increase revenue base is like shifting the goal post after the ball has been put into the net. This may lead to disinvestment. The new directive of making it illegal to use tax consultants by all tiers of government and mandating police to arrest those involved in collecting taxes outside the ones listed in The Taxes and Levies (Approved Rates for Collection) Act, 1998 will go a long way to put sanity to business environment. Healthy business environment will lead corporate entities to fulfill their corporate social responsibilities to the societies.
\end{abstract}

Keywords: The Taxes and Levies (Approved Rates for Collection) CAP.T2 LFN 2004, Joint Tax Board, Double taxation, Internally Generated Revenue, Tax consultants

\section{Introduction}

The running of government organs cannot be carried out effectively if funds are not available. The major sources of funds to run these organs by most governments all over the word are through taxes collected. These taxes can be direct and indirect. In some instances like Nigeria, there may be only one major source of tax, like petroleum profit tax, which is more than $80 \%$ of the total accruable tax. Any downward trends in prices of these commodities always have crushing and devastating effects on the finances of the governments during the forthcoming periods.

Before modern taxation was introduced into Nigeria, there were many forms of taxes. Empires and kingdoms were run by tolls collected from traders who were moving wares and merchandises from one area to another and farmers were expected to pay taxes from the harvest of their produces. Booties from spoils of war were not exempted. Captives were sometimes used as 'money' to pay taxes on the spoils of war.

In return for taxes collected, basic amenities are provided to the citizenry. Security of lives and property is preeminent in functions rendered to the governed. Infrastructures like good roads, affordable health care services and power are also provided by the governments. The absence of any of these may cause disillusion and apathy towards the government which may result in revolts. The Aba riot of 1929 was carried out by women and the Agbekoya riots of 1969 in the Western state of Nigeria was carried out by peasant farmers who resisted the increase of taxes imposed on them without commensurate basic amenities provided. The peasants in rural areas resisted, for example, to pay taxes for pipeborne water which was not extended to them. The organs of governments (police and army) were often used to quell theses resistances resulting in casualties.

The machineries for collection of taxes are available in all tiers of governments. The Federal Board of Inland Revenue is responsible to collect company's income taxes and petroleum profit taxes, the states are responsible for personal income taxes while the local governments are to collect taxes that are mainly used for the community developments. Taxes on goods imported or manufactured are collected by the Customs and Excise departments. The statutes in Nigeria clearly provide the types of taxes that are collectible by each arm of government. Tax revenues of Federal government are not supposed to be collected by the local or state governments. So also the revenues meant for the local and state government are not to be collected by Federal governments.

The issues of multiple taxes on the same goods and services by different organs of government have now become a disincentive to business and commercial activities. Payment of normal taxes in one part of the country on goods is not an assurance of not paying similar taxes on the same goods en-route its destination across the country. Branded 
company vehicles that have advertisement taxes paid on them in one local government may be required to pay such taxes in all the local governments they are operating, even if moving across without any business being transacted. Goods being transported from one state into other states are being taxed along states that these goods are transversing under various taxes by each state or local government. Herds of cattle from the far north are subjected to various types of taxes across the country before finally getting to their final destinations in the southern parts of the country. Food items like pepper, tomatoes and yams are also subjected to various taxes across the route. It may be up to 12 types of taxes to be paid on tomatoes and pepper from a distance of 12 kilometers before getting to its final destination. Various names were given to these taxes- agric tax, environment tax, pollution tax ad hoc tax, movement tax etc.

On vehicular motors, some states and local governments are subjecting vehicles to various tests hitherto meant for the central governments. Vehicles are to pass smoke emission tests before they can move across the locality. These 'tests' are performed on the roads within minutes after the required taxes are paid. 'Passing' smoke emission test in one state is not a justification for crossing a nearby state that has a similar test on emission of smoke from vehicles.

The telecommunication industry has got more than its fair share in respect of multiple taxes being thrown on the helpless corporate Nigerian citizenry. Ministries, Departments and Agencies (MDA) are collecting taxes from the industry with the aim of generating revenues internally. Charges are imposed not only by these MDAs but by community development areas, resident areas and 'Areas Boys' (Uzor, 2013). These are repeated for every base station in all the 36 states and the Capital Territory. Most of these taxes are collected without any legal basis. Failure to pay often result in vandalisation of equipments which result to poor quality of services rendered. The belief is that as the telecommunication industry is making higher profit than any other sectors of the economy, there is a ready-made and easy source of internally generated revenues. These multiple taxes imposed by MDAs and other various organizations inhibited good economic environment needed for commerce and trade (Ojobo, 2013). Manufacturing firms paying various types of taxes in states and local governments; private businessmen paying same types of taxes on the same products or services being moved across the country and individuals being subjected to various taxes are operating in environments not conducive for real economic growth. Are there justifications for these multifarious taxes being thrown to the economic community? Are there not better alternative ways of generating revenue without necessarily flouting the laws of the land? What are the long-term effects of these multiple taxes on the country and the tax system? These and other similar issues will be discussed in this paper. The rest of the paper is hereafter divided into four sections. Section two is on conceptual framework and literature review while section three is on research methodology. Findings and discussions are in section four. Section five summarizes, concludes and recommends.

\section{Conceptual Framework and Literature Review}

\subsection{Conceptual Framework}

\subsubsection{Tax}

A tax is a compulsory contribution to state revenue, levied by the government on workers' income and business profits, or added to the cost of some goods, services, and transactions. Taxes may be levied by different levels of government, and the inclusion of "compulsory" serves to remind that evasion is punishable by law.

It is also a payment exacted by legislative authority. It goes further to say that tax is not a voluntary payment or donation, but an enforced contribution, exacted pursuant to legislative authority. It is any contribution imposed by government whether under the name of toll, tribute, duty, custom, excise, subsidy, aid, supply, or other name.

The income of individuals and business entities, including corporations are subject to tax. Tax is generally imposed on net profits from business, net gains and other income. The computation of income subject to tax may be determined under accounting principles and conventions. There are clear jurisdictions in respect of what is collectible by the national government and what is collectible by the local governments. It is the responsibility of the Federal Board of Inland Revenue Services to collect the company income tax while the state governments are responsible for personal income tax.

Adams Smith (1776) posited that all subjects of every state ought to contribute towards the support of the government, as nearly as possible, in proportion to their respective abilities; that is, in proportion to the revenue which they respectively enjoy under the protection of the state. This is regarded as the principle of equity or fairness in taxation. Secondly, tax which each individual is bound to pay, ought to be certain and not arbitrary. The time of payment, the manner of payment, the amount to be paid, ought all to be clear and plain to the contributor, and to every other person. 
Furthermore, every tax ought to be levied at the time, or in the manner, in which it is most likely to be convenient for the contributor to pay it. Finally, every tax ought to be so contrived, as both to take out and to keep out of the pockets of the people as little as possible, over and above what it brings into the public treasury of the state.

\subsubsection{Double taxation}

Double taxation occurs when taxes are paid on the same sources of earned income twice. As corporations are considered to have separate and distinct legal personalities from the shareholders, they are treated separately from the owners. This was enunciated by the celebrated case of Salomon vs Salomon (1897). When companies pay out dividends to shareholders, those dividend payments incur income-tax liabilities for the shareholders who receive them even though the earnings that provided the cash to pay the dividends were already taxed at the corporate level (Investopedia, 2013). Double taxation also occur where a country levies tax on an income that has already been taxed in the same or another country (BusinessDictionary, 2013). Double taxation may lead to agreement between two countries that a person living in one country shall not be taxed in both countries on the income earned in the other country.

\subsubsection{Multiple Taxation}

Multiple taxation is a phenomenon which describes an income that is subjected to tax more than once, often by two or more different authorities in a way that may be unfair or illegal. Illegality and unfairness distinguish multiple taxation from double taxation. The former often have the characteristics of being unfair and also illegal. Multiplicity of taxes connotes paying similar taxes on the same or substantially similar tax base. Examples of multiple taxes include Companies Income Tax, Information Technology Tax (NITDA Levy), Education Tax, Nigerian Content Development Levy all of which are based on income or profits and Value Added Tax, Sales Tax and Hotel Consumption Tax which are all based on sales. Multiple taxes should be distinguished from numerous taxes which mean many but different taxes on different tax bases. Multiple taxations in relation to a company or individual is a situation where the same profit or income respectively which is liable for tax in Nigeria has been subjected to tax by another tax authority in Nigeria or another country outside Nigeria. In such situations relief is usually granted to that tax payer for the earlier tax paid or to which he may be liable. Specific arrangements are made with a view to preventing such multiple taxes or to provide relief against it.

\subsection{Literature review}

A firm or any individual that is engaged in any business venture that earns income is subjected to tax. Ojeka (2011) is of the opinion that as tax is an important source of fund for development of the economy and provision of social services, Small and Medium Enterprises surveyed in his work were faced with the problems of high tax rates, multiple taxation, complex tax regulations and lack of proper enlightenment or education about tax related issues. This was also the opinion of Adebisi and Gbegi (2013) that multiple taxation has negative effect on SMEs' survival as 80\% of Nigeria SMEs die before their $5^{\text {th }}$ anniversary. They concluded that one major factor responsible for such untimely deaths is multiple taxation. Atawodi and Ojeka (2012) asserted that taxes for SMEs have been more harmful than beneficial as they increase running costs and slow down growth. Most of the SMEs surveyed are faced with the problems of high tax rates, multiple taxation, complex tax regulations and lack of proper enlightenment or education about tax related issues.

Issues in respect of paying taxes more than one occasion in respect of profits from the same business in the same period were classified as multiple taxations. In 1993, Education tax was introduced in Nigeria to fund the deteriorating educational system. Assessment of education tax goes together with the company income tax. The law regulates $2 \%$ tax on the assessable profits of companies. The National Information Technology Development Agency (NITDA) Act, LFN 2007 stipulates a levy of 1\% on the profit before tax of GSM service providers and all Telecommunication Companies, Cyber Companies and Internet providers, Pension Managers and pension related companies. Banks and other financial Institutions and Insurance companies were also included. This provision, according to Abiola and Asiweh (2012), amounts to duplications and multiplicity of tax since these companies equally pay tax as required by Companies Income Tax Act (CITA).

Onyeukwu (2010) while agreeing that multiple taxation is not healthy for development of corporate entities further asserted that it is a disincentive for their growth and these at times affect their corporate social responsibility where they perceive the host state government as being unfriendly. The establishment of the Joint Tax Board is a laudable act in bringing sanity to the crisscrossing demands for tax by each of these governments. The bane of multiplicity of taxes was 
mitigated by the issuance of taxes and levies approved for collection through Taxes and Levies (Approved List for collection) CAP.T2 LFN 2004. Taxes collectible by all tiers of governments are stated therein.

Salami (2011) asserted that there are more than 500 taxes and levies imposed by various tiers of government in Nigeria apart from those approved by Taxes and Levies (Approved list of Collection) Act. These invariably drive up the cost of doing business and destroy investors' confidence. He further stated that multiple taxation is more common in the Local Government than other tiers of governments.

The issue of multiple taxation is more pronounced in the telecommunication, hospitality and transportation businesses. Agbor (2013) found out in his studies that a typical fast food and restaurant business and bars in Calabar in the South East is taxed within 21 subheads. Some amount to double or multiple taxation while some are introductions not recognized by law. For instance, operational permits are collectible only from kiosks and shops but bigger outfits after paying for business premises are also forced to pay for operational permits. Multiple taxation also manifest in the signpost/advert tax. The jurisdiction for collection of this tax is the local government, but the state also collect tax on the same heading. His result shows that multiple and high rate of tax have impinged negatively on the stability of these businesses and therefore recommends the amendment of the fourth schedule to the 1999 constitution to prune it of excess items which the local government uses to perpetrate multiple and excessive taxation.

There are obvious contradictions in respect of taxes collected by all the tiers of government in Nigeria. Imposing Education tax after payment of corporate tax by companies, accepting revenue from VAT and later imposing sales tax, payment of ground rent and later demanding for tenement rates are all moving spaciously towards the multiple taxation syndromes. In some states the methods used in collecting theses taxes are not only illegal, but dehumanizing and violent (Theodore and Appolos, 2012). They asserted that a proper perusal of the Constitution indicates that the Local Government Councils have no powers to legislate on taxes. They can only collect taxes under the authority of a State law which might empower them to make by-laws. But in most of the 774 local government councils in the country, arbitrary laws that will generate funds are passed.

Multiple taxation could be counterproductive if it is excessively applied. The establishment of the Joint Tax Board is to control the imposition of taxes and levies by the appropriate tiers of government and to ensure that whatever tax imposed is legitimate. In Eti-Osa Local Government vs Rufus Jegede \& Anor, it was mentioned that taxation is the life wire of government expenses from which a responsible government provides for the welfare of its people. It was also said that the issue of the power to impose tax should not be allowed to degenerate into a desperate extortion, usurpation and illegitimate exploitation of the public by the said government (Dongban-Mensem JCA, 2007).

Multiplicity of taxes is one of the major problems facing the country and corporate entities and individuals often complain the ripple effects associated with it. States complain about their fiscal responsibilities and fiscal powers or jurisdiction. In order to fill the gap, states resorted to levying certain taxes, which has led to arbitrariness, harassment and even closure of businesses. To rectify this embarrassing situation, the Taxes and Levies (Approved List for collection) Decree No. 21 of 1998.was enacted (Odusola, 2006).

Nigerian tax system faces a pack of challenges which include non availability of tax statistics, inability to priotise tax efforts and multiplicity of tax. Individuals and corporate bodies according to Micah, Ebere and Umobong (2012), feel the ripple effects associated with duplication of tax.

\section{Research Methodology}

For the purpose of this study, secondary data were used. Relevant materials such as textbooks, Journals, Newspaper and other official documents both in prints and electronics were widely consulted. Available literature on multiple taxation and its effects on Nigerian economy were incorporated into this study.

\section{Findings and Discussion}

Taxes and levies collectible by various tiers of Government were clearly stated in Taxes and Levies (Approved Rates for Collection) Act, 1998. Any tax outside this should be regarded as illegal and inappropriate (Appendix A). Many Ministries, Departments and Agencies (MDAs) impose taxes and levies in order shore up their internally generated revenues. In The Taxes and Levies (Approved Rates for Collection) CAP.T2 LFN 2004, there were 39 different taxes and levies: eight for the Federal Government, eleven for States and twenty for Local governments. But in addition to that, many states and local governments, under the pretext that the numerous levies they impose on corporate bodies and individuals do not yield the anticipated quantum of resources they need, have introduced the concept of Internally Generated Revenue 
(IGR) as another key tax component.

In its Policy Brief on multiple taxation in 2006, The Nigerian Economic Summit Group stated that 80 types of taxes as against 40 approved for the three tiers of government by the Taxes and Levies (Approved List for collection) Decree No. 21 of 1998 were imposed on businesses in Nigeria. The attendant effect was the negative impact these multiple taxations were having on them.

The multiple tax imbroglios are not only limited to organized private sectors but to all facets of business concern in Nigeria. Unauthorized revenue collectors abound all the routes of intercity transport vehicles perpetually demanding tolls from the drivers. Nearly all the bus stops are these revenue collectors planted demanding tolls from the drivers. A journey of ten kilometers may be strewn with about twenty cost centres/ revenue collection points where various tolls are collected throughout the day. Ejiro (2013) described such scenes as "owo da" i.e. where is the money? (in Yoruba language). That is the verbal demand notice normally given to these 'taxpayers' who are given targets. Most of these touts have turned themselves to auditors giving different markings to windscreens of vehicles that have complied with the various payments so as not to be subjected to another tax on the same point while returning.

The issues of tax contractors/consultants being used in most of the states are now worrisome to the business climate of the country. Most of them are only interested in the commissions that will accrue to them thereby encouraging many states to dish out unorthodox modus operandi in collecting levies and taxes. Factories are shut without due process while in other situations, stop work orders are giving to construction companies that have not paid the local levies-all in attempt to reach the target set.

At the 2013 National Revenue summit organised by Centre for Economic Research and Development, Abassi (2013) said some businesses fail because of multiple taxation. But while agreeing to the fact that contracting private agents by some states to collect taxes on commission basis contribute to multiple taxation, he was of the opinion that this has improved debt recovery rate for some of the states but it had however had negative effect on the economy.

The usefulness of taxes collected is a major concern in Nigeria. Most taxes collected fall into wrong hands. Nigeria, according to Omogui (2007) is regarded as one of the countries with the most oppressive tax regimes and is reported to be the only country, out of the 56 member countries in the Commonwealth Association of Tax Administration (CATA) that runs a system of duplicative and multiple taxes. Some of the causes of multiple taxation among other things are seizure of local government funds by their state governments and poor growth of Internally Generated Revenue (IGR) by states and local government councils.

Investors would normally prefer business environments where the laws are not harsh against their businesses to where the rules of the jungles will be the order of the day. Goal posts would not be arbitrarily removed when goals are scored giving flimsy excuses for bending the rules of the game. Many of the foreign telecommunication companies were not aware of the frivolous taxes unbecoming of the country's tax regime. All sort of names are given to fees being collected despite the fact that such are not backed by any law. An instance was Environmental Audit Review and Certification Fee of N30,000 per site introduced by Imo State despite the fact that the same fee was legally backed by Standards and Enforcement Regulations Agency (NESREA) of the federal government. In 2005, Aviation Height Clearance Certification (AHCC) of masts and towers erected were increased by as much as $1000-4000 \%$. It was an instance of such a thing that made the president of the Chartered Institute of Nigeria (CITN) Mr. Femi Jegede said that Nigeria's effort to attract investors would not yield fruit until issues associated with multiple taxations are sorted out by government at all levels. He said investments are getting more expensive because of multiple taxation adding that it is only proper that if an investor has paid tax to the local government such a person should not be made to pay any other tax to the state or federal government.

Wherever the tax regime is harsh and unfriendly in any country, capital will take flight. Most telecommunication companies in Nigeria are willing to build more base stations to address the issue of quality of service but they are constrained by the huge taxes and levies from federal, local and state governments (Ojobo, 2013). In corroborating this, Nwokoro (2013) said that multiple taxation is a huge threat to investment in network expansion and no matter how much telecoms operators invest, if the enabling environment is not in place, the output will not be seen.

The president of the Association of National Accountants of Nigeria (ANAN), Alhaji Sakirudeen Labode, at his inauguration at Abuja on 30th April, 2013 wants the country's tax authorities to take a holistic look at the multiple taxes in the system. Multiple taxes have become a clog in the wheels of progress of the economy which among other things distract businessmen and would-be investors.

Recently, the federal government through the Joint Tax Board has again taken the bold step of banning Federal Ministries, Departments and Agencies (MDAs) from collection of taxes and levies because this is a violation of the law. This is extended to all states and the Inspector-General of Police has been directed to dismantle all road-blocks across 
the federation for tax collection. Commissioners of Police will be required to ensure compliance within states (Okwe, (2013).

\section{Summary, Conclusions and Recommendations}

The issue of multiple taxations was examined in this paper. Various literatures in respect of multiple taxations especially in Nigeria were examined. Double taxation which is often mixed up with multiple taxations was explained. The business environments from the organized private sectors to the sole proprietorships are affected by the negative impact of paying various taxes which are not backed by any law. The Taxes and Levies (Approved Rates for Collection) Act, 1998 clearly stipulated types of taxes collectible by the three tiers of government but caution was thrown to the winds and all sort of fees and taxes were introduced in attempt to increase their revenues. Brutal forces were used to collect these unauthorized taxes and where construction is ongoing, stop work orders are issued.

With the various types of taxes being collected by all government agencies in the country, the environment is clearly not conducive to investors. Investors coming to the country would have carried out feasibility studies about the profitability of the businesses. To introduce taxes that are not backed by any law in the land is like shifting the goal post after the ball has been put into the net. What such a thing may lead to is disinvestment. The telecommunication companies, for example, are subjected to various types of taxes that are unknown in any developing country.

The new directive of making it illegal to use tax consultant by any tier of government and arresting those who are involved in collection of taxes that are not backed by any law is a welcome idea. Many states have cried blue murder in respect of this. But if the business environment is healthy, these corporate entities would fulfill their corporate social responsibilities to the societies.

\section{References}

Abassi, K. (2013) Why some businesses fail — FIRS Retrieved from http://www.vanguardngr.com/ on Monday December 9, 2013

Abiola, J. and Asiweh, M (2012) Impact of Tax Administration on Government Revenue in a Developing Economy - A Case Study of Nigeria International Journal of Business and Social Science Vol. 3 No. 8 [Special Issue - April 2012]

Adebisi, J. F and Gbegi, D. O. (2013) Effect of Multiple Taxation on the Performance of Small and Medium Scale Business Enterprises. (A Study of West African Ceremics, Ajeokuta, Kogi State) Mediterranean Journal of Social Sciences Published by MCSERCEMAS-Sapienza University of Rome Vol. 4 No 6 July 2013 E-ISSN 2039-2117ISSN 2039-9340

Agbor, U. I. (2013) Getting the Money and Plummeting Business Development: A study of the Impact of Tax regime on Hospitality Industry in Calabar, Nigeria Global Journal of Political Science and Administration Vol. 1, No. 1, pp. 16-26, September 2013 www.ea-journals.org

Atawodi, O. A and Ojeka, S. A (2012) Relationship between Tax Policy, Growth of SMEs and the Nigerian Economy International Journal of Business and Management; Vol. 7, No. 13; 2012 ISSN 1833-3850 E-ISSN 1833-8119

BusinessDictionary (2013) Double taxation Retrieved from www.businessdictionary.com/definition/double-taxation.htm on Friday October 25,2013

Dongbon-Memsem (2007) Commercial Law Reports Nigeria, Annual Review 2007 p 45 ISSN0189-7535

Ejiro, O. (2013) Forever owo da, BusinessDay Newspaper, October 15, p38

Investopedia, (2013) Double taxation Retrieved from www.investopedia.com/terms/d/double_taxation.asp on Friday October 18, 2013

Jegede, F. (2012) Nigeria multiple taxation scares investors Retrieved from www.frontiersnews.com/.../641-nigerias-multiple-taxationscares-investo.. on Wednesday October 2, 2013

Labode, S.T. (2013) ANAN tasks govt on multiple tax regime Acceptance speech by alhaji sakirudeen tunji labode, fcna on his investiture as the 8th president of association of national accountants of nigeria (anan) anan.org.ng/...h-by-chief-sakirudeen-tunjilabode.pdf

Micah, L. C, Ebere, C and Umobong, A. A. (2012) Tax System in Nigeria - Challenges and the Way Forward Research Journal of Finance and Accounting ISSN 2222-1697 (Paper) ISSN 2222-2847 (Online) Vol 3, No 5, 2012 www.iiste.org

NESG Policy Brief, Multiple Taxation in Nigeria No. 2 September, 2006

Nwokoro, O. (2013) Tax burden may slow N979bn investment in network expansion Retrieved from http://www.businessdayonline.com Itax-burden-may-slow-n979bn-investment-in-n on Thursday October 31, 2013

Odusola, A. (2006) Tax Policy Reforms in Nigeria, United Nations University: UNU-WIDER, Research Paper No. 2006/03, Jan. 2006), 8 www.rrojasdatabank.info/unurp06/rp2006-

Ojeka, S. A. (2011) Tax Policy and the Growth of SMEs: Implications for the Nigerian Economy Research Journal of Finance and Accounting Vol. 2, No 2, 2011 ISSN 2222-1697 (Paper) ISSN 2222-2847 (Online)

Ojiro, O.(2013) Forever owo da unauthorized revenue collectors compound the problems of small business in Lagos BusinessDay Wednesday October 2, 2013 p 38

Ojobo, T (2013). Telcos N979bn network upgrade caught in web of state taxes Retrieved from http://www.businessdayonline.com/ on 
Sunday November 3, 2013

Ojobo, T. (2013?) Tax is a disincentive for investment Retrieved from http://www.businessdayonline.com/tax-burden-may-slow-n979bninvestment-in-n on Thursday October 31, 2013

Okwe, M. (2013) Govt bans tax contractors in states, IGP to enforce policy Retrieved from www.ngrguardiannews.com/.../136351-govtbans-tax-contractors-in-stat on Monday November 25, 2013

Omogui, I (2007) FIRS Boss, Advises Businessmen On Multiple Taxation Retrieved from www.thenigeriabusiness.com > Corporate Governance on Monday December 9, 2013

Onyeukwu, H (2010) Business Tax in Nigeria: The Controversy of Multiple Taxation

Retrieved from http://works.bepress.com/humphrey_onyeukwu on Wednesday, 272013

Osita, Aguolu (2004). Taxation and Tax Management in Nigeria. Meridian Association 36, Zik Avenue, Uwani, Enugu.

Retrieved from http://works.bepress.com/humphrey_onyeukwu on Wednesday, 272013

Salami, A (2011) Taxation, Revenue Allocation and Fiscal Federalism in Nigeria: Issues, Challenges and Policy Options ECONOMIC ANNALS, Volume LVI, No. 189 / April - June 2011 www.doiserbia.nb.rs/ft.aspx?id=0013-32641189027S

Salomon vs Salomon (1897) www.bloomsburyprofessionalonline.com/view/...law/bp-N38877s.xml

Smith, A. (1776) An Inquiry into the Nature and Causes of the Wealth of Nations. 1776. Accessible at http://www.gutenberg.org letext/3300.

Tax: http://www.oxforddictionaries.com/view/entry/m_en_gb0846930\#m_en_gb0846930

Taxes and Levies (Approved list for collection) Decree No. 21 of 1998 Laws of the Federation of Nigeria www.commonlii.org>

The National Information Technology Development Agency ACT 2007 Third Schedule Section 12 (2) (a) www.nitda.gov.ng

Theodore, U. D and Appolos, N. N (2012) Impact of Heavy Taxation on Israel During Solomonic Era: Implications for Nigerian Tax System Asian Economic and Financial Review, Vol. 2, pp.337 346

Uzor, B (2013) Telcos N979bn network upgrade caught in web of state taxes Retrieved from http://www.businessdayonline.com/ on Sunday November 3, 2013

www.frontiersnews.com/.../641-nigerias-multiple-taxation-scares-investo.. on Wednesday October 2, 2013

www.ncc.gov.ng/index.php?option=com docman\&task=doc... Position Paper on Hazards and Further Implications of Multiple Taxation and Regulation of the Communications Industry in Nigeria. Retrieved on Sunday November 3, 2013 


\section{Appendix}

Taxes and Levies (Approved list for collection) CAP.T2 LFN 2004

\begin{tabular}{|c|c|c|}
\hline Federal Government & State Government & Local Government \\
\hline 1. Companies income tax & $\begin{array}{l}\text { 1. Personal Income Tax in respect of - } \\
\text { (a) Pay-As-You Earn (PAYE) } \\
\text { (b) Direct Taxation (Self Assessment } \\
\text { 2. Withholding tax (individuals only). }\end{array}$ & $\begin{array}{l}\text { 1. Shops and kiosks rates. } \\
\text { 2. Tenement rates. } \\
\text { 3. On and Off Liquor Licence fees. }\end{array}$ \\
\hline $\begin{array}{l}\text { 2.Withholding tax on companies, residents of } \\
\text { the Federal Capital Territory, Abuja and non- } \\
\text { resident individuals. }\end{array}$ & 3. Capital gains tax (individuals only). & $\begin{array}{l}\text { 4. Slaughter slab fees } \\
\text { 5. Marriage, birth and death registration fees. }\end{array}$ \\
\hline 3. Petroleum profits tax. & $\begin{array}{l}\text { 4.Stamp duties on instruments executed } \\
\text { by individuals. }\end{array}$ & 6. Signboard and Advertisement permit fees \\
\hline 4. Value added tax. & $\begin{array}{l}\text { 5. Pools betting and lotteries, gaming } \\
\text { and casino taxes }\end{array}$ & $\begin{array}{l}\text { 7. Naming of street registration fee, excluding } \\
\text { any street in the State Capital. }\end{array}$ \\
\hline 5. Education tax. & 6. Road taxes. & $\begin{array}{l}\text { 8. Right of Occupancy fees on lands in rural } \\
\text { areas, excluding those collectable by the } \\
\text { Federal and State Governments. }\end{array}$ \\
\hline $\begin{array}{l}\text { 6. Capital gains tax on residents of the } \\
\text { Federal Capital Territory, Abuja, bodies } \\
\text { corporate and non-resident individuals }\end{array}$ & $\begin{array}{l}\text { 7. Business premises registration fee in } \\
\text { respect of - } \\
\text { (a) urban areas as defined by each } \\
\text { State, maximum of } \\
\text { (i) N10,000 for registration, and } \\
\text { (ii) N5,000 per annum for renewal of } \\
\text { registration; and } \\
\text { (b) rural areas - } \\
\text { (i) N2,000 for registration, and } \mathrm{N} 1,000 \\
\text { per annum for renewal of registration }\end{array}$ & $\begin{array}{l}\text { 9. Market taxes and levies excluding any } \\
\text { market where State finance is involved. }\end{array}$ \\
\hline $\begin{array}{l}\text { 7. Stamp duties on bodies corporate and } \\
\text { residents of the Federal Capital Territory, } \\
\text { Abuja. }\end{array}$ & $\begin{array}{l}\text { 8. Development levy (individuals Only) } \\
\text { not more than N } 100 \text { per annum on all } \\
\text { taxable individuals. } \\
\text { 9. Naming of street registration fees in } \\
\text { the State Capital. } \\
\text { 10. Right of Occupancy fees on lands } \\
\text { owned by the State Government in } \\
\text { urban areas of the State. }\end{array}$ & $\begin{array}{l}\text { 10. Motor park levies. } \\
\text { 11. Domestic animal licence fees } \\
\text { 12. Bicycle, truck. canoe, wheelbarrow and cart } \\
\text { fees, other than a mechanically propelled truck. } \\
\text { 13. Cattle tax payable by cattle farmers only. } \\
\text { 14. Merriment and road closure levy. } \\
\text { 15. Radio and television licence fees (other } \\
\text { than radio and television transmitter). }\end{array}$ \\
\hline $\begin{array}{l}\text { 8. Personal income tax in respect of - } \\
\text { (a) members of the Armed Forces of the } \\
\text { Federation; } \\
\text { (b) members of the Nigeria Police Force; } \\
\text { (c) residents of the Federal } \\
\text { Capital Territory, Abuja; and } \\
\text { (d) staff of the Ministry of Foreign Affairs and } \\
\text { non-resident individuals }\end{array}$ & $\begin{array}{l}\text { 11. Market taxes and levies where } \\
\text { State finance is involved. }\end{array}$ & $\begin{array}{l}\text { 16. Vehicle radio licence fees (to be imposed } \\
\text { by the Local Government of the State in which } \\
\text { the car is registered). } \\
\text { 17. Wrong parking charges. } \\
\text { 18. Public convenience, sewage and refuse } \\
\text { disposal fees. } \\
\text { 19. Customary burial ground permit fees. } \\
\text { 20. Religious places establishment permit fees }\end{array}$ \\
\hline
\end{tabular}

Source: Taxes and Levies (Approved list for collection) Decree № 21 of 1998 